\title{
Role of Opioid Receptors in Bombesin-induced Grooming ${ }^{a}$
}

\author{
DEBRA E. GMEREK ${ }^{b}$ AND A. COWAN ${ }^{c}$ \\ ${ }^{b}$ Department of Pharmacology \\ University of Michigan Medical School \\ Ann Arbor, Michigan 48109-0010 \\ 'Department of Pharmacology \\ Temple University School of Medicine \\ Philadelphia, Pennsylvania 19140
}

\section{INTRODUCTION}

Bombesin, a tetradecapeptide originally isolated from the skin of the frog Bombina bombina, ' elicits dose-related excessive grooming when injected centrally in rats ${ }^{2-4}$ as well as other species. ${ }^{3}$ The grooming induced by intracerebroventricular (i.c.v.) bombesin in rats consists of hindlimb scratching directed primarily at the head and neck, although facial grooming, body washing, nail licking and biting, forepaw tremors, wetdog shakes, and stretching also occur. Bombesin-induced grooming behavior can be observed within a few minutes of i.c.v. injection and continues for 30-45 minutes.

In contrast to the grooming induced by a variety of other peptides such as $\mathrm{ACTH}_{1-24}$, thyrotropin-releasing hormone, substance $P, \beta$-endorphin, and nonpeptides such as RX 336-M (7,8-dihydro-5',6'-dimethylcyclohex-5'-eno-1',2', $8^{\prime}, 14$ codeinone), bombesininduced grooming is not inhibited by nonsedative doses of morphine. ${ }^{6-11}$

In keeping with multiple types of cholinergic, adrenergic, histaminic, and dopaminergic receptors, it is also well established that there are multiple types of opioid receptors. Based on observations in dogs, the existence of three types of opioid receptors was postulated: mu (for which morphine was the prototype), kappa (for which ketocyclazocine was the prototype) and sigma (for which $\mathrm{N}$-allyl-normetazocine was the prototype). ${ }^{12,13}$ Since then, mu and kappa types of opioid receptors have been differentiated by biochemical studies using receptor binding and visualization techniques (see, for example, refs. 14 and 15) and by pharmacological studies in which differences in acute effects, differences in the ease of antagonism by the opioid-specific antagonist naloxone, and the selective development of tolerance and dependence were identified (see refs. 16-18). Whereas sigma receptors are no longer considered to be opioid (i.e., naloxone is not an antagonist of effects mediated by the "sigma" receptor), a third type of opioid receptor has been identified primarily through in vitro studies, the delta receptor. ${ }^{19}$ The endogenous enkephalins have been proposed as natural ligands for the delta receptor.

In light of the multiple classes of opioids, we decided to examine opioids other than morphine for their ability to inhibit bombesin-induced grooming in rats. In our

\footnotetext{
${ }^{a}$ This work was supported by NIH grant no. BRSG S07 RR05417 and USPHS grant nos. DA 03681 and DA 00254.
} 
preliminary studies, ${ }^{\mathbf{8 9 . 2 0}}$ it became evident that ethylketazocine (a compound structurally and pharmacologically related to ketazocine) could antagonize bombesin-induced grooming. It was therefore decided to study further the role of opioid receptors in the modulation of bombesin-induced grooming.

Ethylketocyclazocine, and more recently tifluadom and U-50,488 (trans-3,4-dichloro$N$-methyl- $N$-[2-(pyrrolidinyl)cyclohexyl-1]benzeneacetamide), have been used as prototypical kappa agonists. Ethylketazocine is a benzomorphan showing selectivity for kappa receptors in binding assays as well as in most tests in vitro and in vivo. It can act through mu receptors, however, to produce hot water tail-withdrawal analgesia and inhibit gastrointestinal transit in rats. ${ }^{21}$ Tifluadom is a very interesting compound in that it has the structure of a benzodiazepine but little or no activity at benzodiazepine receptors; it has been found to be very selective for the kappa type of opioid receptor, however. ${ }^{22.23} \mathrm{U}-50,488$ is a compound of novel structure for opioids. ${ }^{24}$ In binding studies, U- 50,488 has a selectivity of approximately 250 -fold for kappa over mu or delta binding sites in quinea pig brain. ${ }^{25}$ It has a strictly kappa profile of activity both in vitro and in vivo (see, for example, refs. 18, 24, 26, and 27).

In this work, the role of opioid receptors in bombesin-induced grooming was investigated by means of classical methods in opioid pharmacology: by classification of opioid-like compounds on the basis of their ability to inhibit the grooming elicited by a standard submaximal dose of bombesin; by examination of the stereospecificity of the interaction between the opioid and bombesin; by examination of the sensitivity of the opioids to naloxone; and through tolerance and cross tolerance studies.

\section{METHODS}

\section{Animals and Surgery}

Male Sprague-Dawley albino rats weighing $180-200 \mathrm{~g}$ were each implanted with a stainless steel cannula (Plastic Products Co., Roanoke, VA) directed towards the lateral cerebral ventricle as described previously. ${ }^{\star}$ The rats were housed individually at $23 \pm$ $1^{\circ} \mathrm{C}$ with free access to food and water for at least 4-7 days before testing. They were exposed to a 12-h timer-regulated light period from 7 A.M. to 7 P.M.

\section{General Procedure}

Experiments were carried out in the afternoons. At least $15 \mathrm{~min}$ before testing, the rats were transfered from their home cages and placed individually in Plexiglas observation boxes ( $22 \mathrm{~cm}$ long; $18 \mathrm{~cm}$ wide; $25 \mathrm{~cm}$ high). Four rats were monitored at a time with the aid of a portable microcomputer as described previously. ${ }^{11.28}$ Test compounds, with the exception of dynorphin $A$, were injected 15 min prior to a standard submaximal groom-inducing dose of bombesin ${ }^{4}(0.1 \mu \mathrm{g}, \mathrm{i} . \mathrm{c.v}$.$) . Dynorphin A$ and [D-Pen-2,D-Pen-5] enkephalin were given i.c.v. $5 \mathrm{~min}$ before bombesin (0.1 $\mu \mathrm{g}, \mathrm{i} . \mathrm{c.v}$.$) .$

\section{Quantification of Behavior}

Beginning immediately after the last bombesin or i.c.v. saline control injection, each rat was observed for $5 \mathrm{~s}$ out of every $20 \mathrm{~s}$ for a total of $30 \mathrm{~min}$. A positive grooming score was given if the rat demonstrated any type of grooming behavior (e.g., scratching, 
washing, licking, biting, etc.) during the 5-s observation period. Consequently, there was a total of 90 grooming episodes scored.

Results are presented as the \%MGE (maximum number of grooming episodes scored as positive) \pm SEM. The \%MGE was calculated for each rat (i.e., number of positive grooming scores times 100 , divided by 90 ). Groups of at least five rats were used to determine each data point. Intracerebroventricular saline control animals had \%MGE scores of $6 \pm 1$. If, following the pretreatment with a test compound and bombesin administration, the majority of rats had \%MGE of less than 6, their grooming behavior was said to be suppressed. Compounds were said to have the ability to antagonize bombesin-induced grooming only if they inhibited the scratching behavior in a doserelated manner at doses that did not suppress grooming behavior below i.c.v. saline controls.

Absolute grooming scores were analyzed statistically by means of ANOVA followed by Dunnett's test or the Mann-Whitney U-test, as appropriate. ${ }^{29}$ Percent inhibition of bombesin-induced grooming was calculated as follows:

1-(bombesin grooming score in opioid-pretreated rats - saline controls)

(bombesin grooming score in saline-pretreated rats - saline controls) $\times 100$.

$A_{s 0}$ values (i.e., doses at which test compounds antagonize an effect by $50 \%$ ) were determined by linear regression analysis ${ }^{30}$ of absolute data from which saline control values had been subtracted. Confidence limits $(95 \%)$ of $A_{s o}$ values were also determined.

\section{Compounds and Injections}

The following compounds were used: azidomorphine bitartrate (J. Knoll, Semmelweise University of Medicine, Budapest, Hungary), bombesin (Sigma and Boehringer Mannheim, Indianapolis, IN), bremazocine HCl (D. Romer, Sandoz, Basel, Switzerland), buprenorphine $\mathrm{HCl}$ (National Institute on Drug Abuse, Rockville, MD), codeine phosphate (Merck Sharp \& Dohme, West Point, PA), cyclazocine (Sterling-Winthrop, Rensselaer, NY), dextrorphan (NIDA), dynorphin A (Penninsula Laboratories, Belmont, Calif.), $\beta$-endorphin (A. A. Manian, National Institute of Mental Health, Bethesda, MD), [D-Pen-2,D-Pen-5]enkephalin (DPDPE, Penninsula), ethylketazocine methanesulfonate (EKC, Sterling-Winthrop), $d$-EKC and l-EKC (Sterling-Winthrop), ethylmorphine $\mathrm{HCl}$ (Merck Sharp \& Dohme), heroin $\mathrm{HCl}$ (NIDA), ketocyclazocine methanesulfonate (Sterling-Winthrop), levorphanol tartrate (Hoffmann-La Roche, Nutley, NJ), meperidine $\mathrm{HCl}$ (Sterling-Winthrop), methadone $\mathrm{HCl}$ (NIDA), metkephamid (R. C. A. Frederickson, Eli Lilly Co., Indianapolis, IN), morphine sulfate (Mallinckrodt Inc., St. Louis, MO), nalbuphine $\mathrm{HCl}$ (Endo Laboratories, Inc., Garden City, NY), nalorphine $\mathrm{HCl}$ (Sigma), $d$-naloxone $\mathrm{HCl}$ and $l$-naloxone $\mathrm{HCl}$ (A. Jacobson, National Institutes of Health, Bethesda, MD), naloxone $\mathrm{HCl}$ (Endo), l-pentazocine (SterlingWinthrop), phenazocine $\mathrm{HBr}$ (Smith Kline \& French, Philadelphia, PA), quadazocine methanesulfonate (also known as Win 44,441-3; Sterling-Winthrop), thebaine (NIDA), racemic tifluadom, (+)- and (-)-tifluadom (referring to the optical rotation as measured in ethanol; Kali-Chemi AG, Hannover, FRG), U-50,488 (trans-3,4-dichloro- $N$ methyl- $N$-[2-(pyrolidinyl)cyclohexyl-1]benzeneacetamide) (J. Collins, Upjohn Co., Kalamazoo, MI), xorphanol mesylate (H. G. Pars, Pharmaceutical Laboratories, Inc., Cambridge, MA), and zomepirac (McNeil Laboratories, Fort Washington, PA).

The alkaloids were dissolved in a minimal volume of glacial acetic acid, if necessary, and diluted with saline. Tifluadom (racemic and optical isomers) were dissolved 
in a solution of $40 \%$ propylene glycol, $10 \%$ ethanol, $5 \%$ sodium benzoate and benzoic acid, and $15 \%$ benzyl alcohol by sonication and heat. Injections were given s.c. in volumes of $1 \mathrm{ml} / \mathrm{kg}$ with doses calculated as the base or salt as indicated above; the dose of $d$ - and $l$-naloxone was calculated as the free base. Aliquots of bombesin, DPDPE, dynorphin $A$, and $\beta$-endorphin were each dissolved in saline daily as needed. Bombesin, DPDPE, dynorphin $A$ and $\beta$-endorphin were injected i.c.v. to hand-held, conscious rats in volumes of 3-4 $\mu$ l followed by $0.5-1 \mu \mathrm{l}$ saline wash.

\section{RESULTS}

\section{Opioid Classification}

The following compounds given as $15 \mathrm{~min}$ s.c. pretreatments to a standard $0.1 \mu \mathrm{g}$ dose of i.c.v. bombesin did not attenuate bombesin-induced grooming at nonsedative doses, i.e., doses that did not suppress grooming behavior below i.c.v. saline controls (highest nonsedative dose used in $\mathrm{mg} / \mathrm{kg}$, s.c., in parentheses): azidomorphine (0.05), buprenorphine (0.5), codeine (40), dextrorphan (30), ethylmorphine (100), heroin (0.5), levorphanol (1), meperidine (25), methadone (1), metkephamid (30), morphine (10), nalbuphine (10), naloxone (10), and thebaine (25). $\beta$-Endorphin $(10 \mu \mathrm{g}$, i.c.v.) given

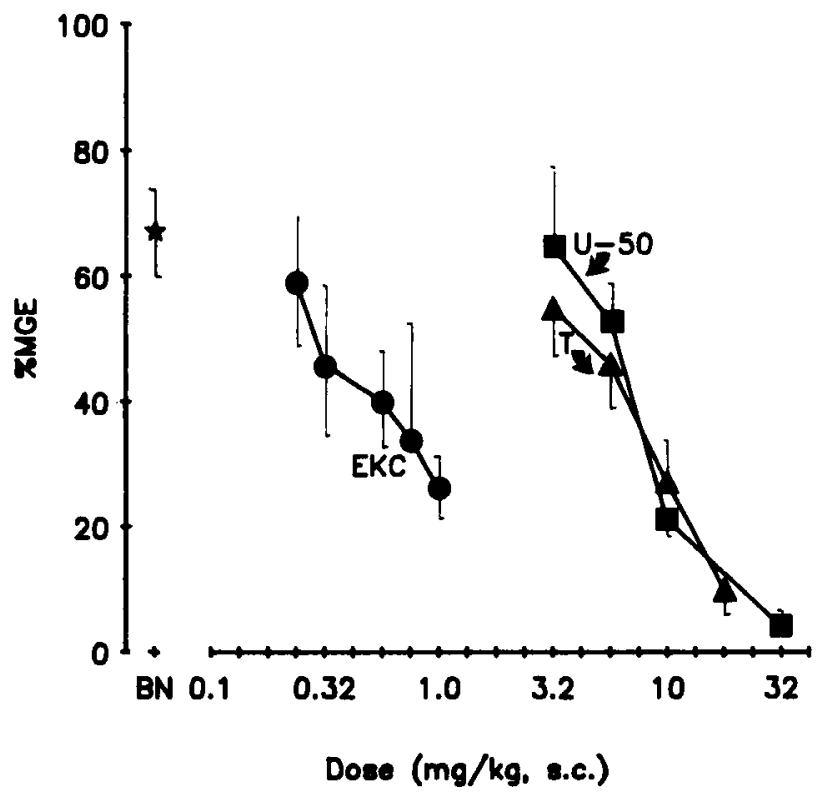

FIGURE 1. The effect of 15 -min pretreatment with ethylketazocine methanesulfonate $(E K C)$, $\mathrm{U}-50,488(U-50)$, or tifluadom $(T)$ on the grooming induced by bombesin $(0.1 \mu \mathrm{g}$, i.c.v.). $\% M G E$ is the percentage of the maximum number of grooming episodes scored as positive during the 30-min observation session. Data points indicate the mean \pm SE for 5-8 rats. $B N$ : \%MGE following saline $(1 \mathrm{ml} / \mathrm{kg}$, s.c.) pretreatment. 


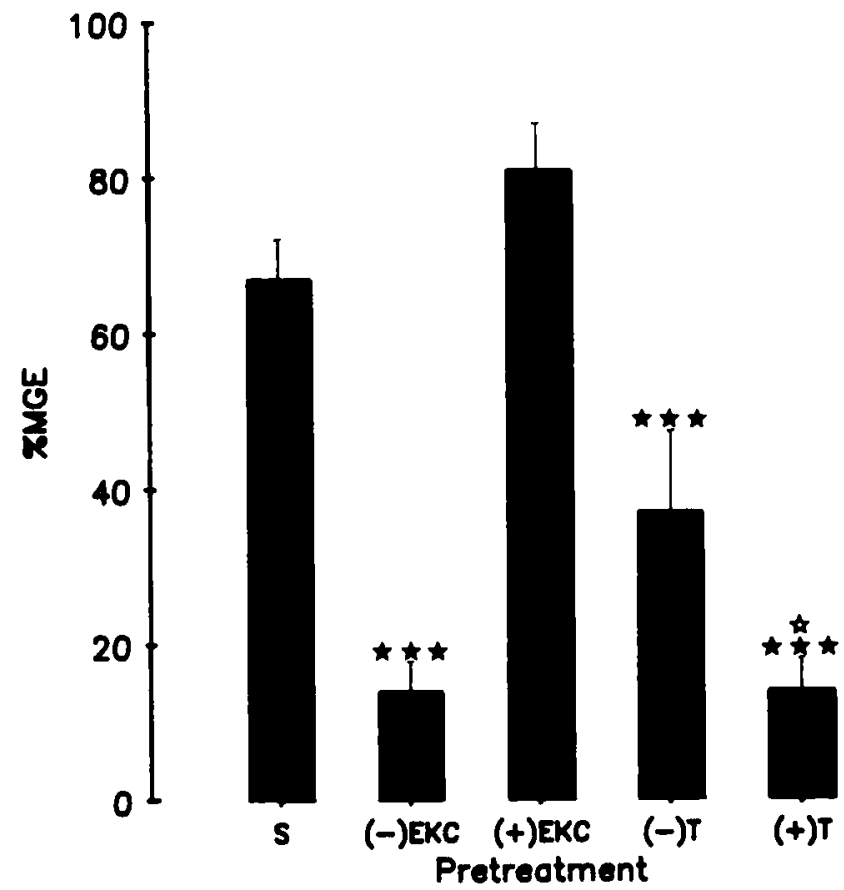

FIGURE 2. The effect of $15-\mathrm{min}$ pretreatment with saline $(1 \mathrm{ml} / \mathrm{kg}$, s.c.), the stereoisomers of EKC (both $0.5 \mathrm{mg} / \mathrm{kg}$, s.c.), or the optical isomers of tifluadom ( $T$, both $10 \mathrm{mg} / \mathrm{kg}$, s.c.) on the grooming induced by bombesin $(0.1 \mu g$, i.c.v.). \%MGE is the percentage of the maximum number of grooming episodes scored as positive over the 30 -min observation session. Bars indicate the mean \pm SE for 5-8 rats; $* * p<0.001$, ANOVA and Mann-Whitney U-test compared to saline + bombesin controls; $p=0.02$, ANOVA and Mann-Whitney U-test compared to (-)-tifluadom + bombesin.

$15 \mathrm{~min}$ before bombesin or DPDPE ( 1 and $5 \mu \mathrm{g}$, i.c.v.) given $5 \mathrm{~min}$ before bombesin also did not attenuate bombesin-induced grooming at doses that did not produce competing behaviors (catalepsy and rearing, respectively). Zomepirac ( $5 \mathrm{mg} / \mathrm{kg}, \mathrm{s.c}$.) had no marked effect on bombesin-induced grooming.

Bremazocine $(10 \mathrm{mg} / \mathrm{kg})$, cyclazocine $(5 \mathrm{mg} / \mathrm{kg})$, ketazocine $(1 \mathrm{mg} / \mathrm{kg}), l$-pentazocine $(20 \mathrm{mg} / \mathrm{kg})$, and phenazocine $(0.5 \mathrm{mg} / \mathrm{kg})$ attenuated bombesin-induced grooming significantly compared to saline + bombesin controls $(p<0.001$; ANOVA followed by Dunnett's test for multiple comparisons) at nonsedative doses (\%MGE scores remained greater than i.c.v. saline controls). Xorphanol attenuated bombesin-induced grooming in a dose-related manner with an $A_{s o}$ of $0.71(0.41-1.21) \mathrm{mg} / \mathrm{kg}$, s.c. Dynorphin $A$ also antagonized bombesin-induced grooming in a dose-related manner with an $A_{s 0}$ of 4.1 (2.8-5.9) $\mu \mathrm{g}$, i.c.v.

FIGURE 1 shows the dose-related decrease in bombesin-induced grooming produced by EKC, U-50,488, and tifluadom. The $A_{s o}$ 's for EKC, tifluadom, and U-50,488 to antagonize bombesin-induced grooming were $0.36(0.33-0.40), 6.61(5.37-8.13)$, and $6.80(5.52-8.36) \mathrm{mg} / \mathrm{kg}$, respectively. 
TABLE 1. Naloxone Antagonism of the Effect of s.c. EKC $(0.5 \mathrm{mg} / \mathrm{kg}), \mathrm{U}-50,488$ $(10 \mathrm{mg} / \mathrm{kg})$, and Tifluadom $(10 \mathrm{mg} / \mathrm{kg})$ on Bombesin-induced Grooming $(0.1 \mu \mathrm{g}$, i.c.v.).

\begin{tabular}{cl}
\hline Opioid Agonist & $\begin{array}{c}\text { Naloxone } \mathrm{A}_{\mathbf{s 0}}\left(95 \% \text { C.L. }{ }^{a}\right), \\
\mathrm{mg} / \mathrm{kg}, \text { s.c. }\end{array}$ \\
\hline EKC & $0.076(0.068-0.086)$ \\
Tifluadom & $0.12(0.08-0.20)$ \\
U-50,488 & $0.43(0.30-0.60)$ \\
\hline
\end{tabular}

${ }^{a}$ Confidence limit.

\section{Stereoselectivity of EKC and Tifluadom}

FIGURE 2 shows the stereoselectivity of EKC and tifluadom in their ability to antagonize bombesin-induced grooming. The levorotatory enantiomer, but not the dextrorotatory enantiomer, of EKC inhibited bombesin-induced grooming. Whereas both isomers of tifluadom antagonized bombesin-induced grooming, the (+)-optical isomer of tifluadom was significantly more effective than the $(-)$-isomer.

\section{Sensitivity to Naloxone}

Naloxone itself, up to $10 \mathrm{mg} / \mathrm{kg}$, had no effect on bombesin-induced grooming. Naloxone, however, reversed the effects of EKC, tifluadom, and U-50,488 (doses that inhibited bombesin-induced grooming by approximately $80 \%$ ) in a dose-related manner. TABLE 1 shows the potency of naloxone against the effects of the three kappa agonists on bombesin-induced grooming. This action of naloxone was stereospecific in that l-naloxone $(0.08 \mathrm{mg} / \mathrm{kg})$ prevented the action of $0.5 \mathrm{mg} / \mathrm{kg} \mathrm{EKC} \mathrm{on} \mathrm{bombesin-induced}$ grooming significantly $(p<0.01)$, whereas $d$-naloxone $(0.1 \mathrm{mg} / \mathrm{kg})$ had no effect on the ability of the same dose of EKC to attenuate bombesin-induced grooming (data not shown).

TABLE 2. Effect of Multiple Injections of EKC or Morphine on the Ability of EKC to Attenuate Bombesin-induced Grooming

\begin{tabular}{lcc}
$\begin{array}{l}\text { Treatment } \\
(8 \times)\end{array}$ & Challenge $^{b}$ & $\begin{array}{c}\text { Bombesin-induced Grooming } \\
(\% \mathrm{MGE} \pm \text { SEM) }\end{array}$ \\
\hline saline & saline & $68 \pm 3$ \\
saline & EKC & $20 \pm 4^{c}$ \\
EKC & saline & $73 \pm 6$ \\
EKC & EKC & $85 \pm 4^{d}$ \\
morphine & saline & $62 \pm 6$ \\
morphine & EKC & $23 \pm 4$ \\
\hline
\end{tabular}

\footnotetext{
${ }^{a}$ Eight injections over consecutive days as described in REsults.

${ }^{b}$ Challenge with saline $(1 \mathrm{ml} / \mathrm{kg}$, s.c. $)$ or EKC $(0.5 \mathrm{mg} / \mathrm{kg}$, s.c. $)$ was given $19-20 \mathrm{~h}$ after the eighth injection of saline, EKC, or morphine, and 15 min before bombesin $(0.1 \mu \mathrm{g}$, i.c.v.).

${ }^{c} p<0.001$, ANOVA followed by the Mann-Whitney U-test compared to saline + saline controls.

${ }^{p}<0.001$, ANOVA followed by the Mann-Whitney U-test compared to saline + EKC controls.
} 


\section{Tolerance Studies}

Morphine was given at 5 P.M. and 8 A.M. at doses of 10, 10, 30, 30, 100, 100, 100, and $100 \mathrm{mg}$ per $\mathrm{kg}$ per injection for a total of eight injections over consecutive days to two groups of eight rats. EKC was given eight times over consecutive days at the doses of $5,5,10,10,20,20,20$, and $20 \mathrm{mg}$ per $\mathrm{kg}$ per injection to two groups of rats. Another two groups of rats received twice-daily injections of saline $(1 \mathrm{ml} / \mathrm{kg}, \mathrm{s.c}$.) for four consecutive days. Beginning 19-20 h after the last of the multiple morphine, EKC, or saline injections, the rats were challenged with saline $(1 \mathrm{ml} / \mathrm{kg}$, s.c.) or EKC $(0.5$ $\mathrm{mg} / \mathrm{kg}, \mathrm{s.c}$ ) and followed $15 \mathrm{~min}$ later with the standard dose of bombesin $(0.1 \mu \mathrm{g}$, i.c.v.) as indicated in TABLE 2. Multiple treatments with saline, morphine, or EKC had no effect on bombesin-induced grooming. Multiple injections of morphine also did not affect the ability of EKC to attenuate bombesin-induced grooming. However, multiple injections of EKC decreased significantly $(p<0.001)$ the ability of EKC $(0.5 \mathrm{mg} / \mathrm{kg})$ to inhibit bombesin-induced grooming; i.e., tolerance developed to EKC.

\section{DISCUSSION}

The excessive grooming (scratching) behavior elicited by a standard submaximal dose of bombesin was attenuated in a dose-related and stereoselective manner by opioids showing activity at the kappa type of receptor. These included benzomorphan analgesics; the endogenous kappa-selective opioid peptide, dynorphin A; a morphinan mixed agonist-antagonist analgesic of the kappa type, xorphanol; and the most kappa-receptorselective opioid available, $U-50,488$. It is important to note that the inhibition of bombesin-induced grooming by these opioids occurred in a dose-related fashion and at doses that did not obliterate natural grooming behavior.

In contrast, compounds whose agonist effects are thought to be mediated by the mu or delta types of opioid receptors were unable to affect bombesin-induced scratching at doses that did not completely suppress grooming behavior. Most of these compounds eventually prevented bombesin-induced grooming, but it was not a dose-related effect, and grooming behavior was prevented altogether: \%MGE scores were below those of i.c.v. saline controls. These included the prototype mu-receptor agonist, morphine; the prototype delta-receptor agonist, DPDPE; and a mixed agonist-antagonist analgesic of the mu-type, nalbuphine. In addition, the nonopioid analgesic, zomepirac, had no marked effect on bombesin-induced grooming.

Ethylketazocine, tifluadom, and U-50,488 were examined more thoroughly as prototype kappa opioid agonists in their ability to affect bombesin-induced grooming. All three compounds inhibited bombesin-induced grooming in a dose-related and parallel manner. Ethylketazocine was approximately 18 times as potent as U-50,488 and tifluadom, which were equipotent. A similar potency relationship has been observed among EKC and U-50,488 and tifluadom in the rat tail-immersion test. ${ }^{24,31} \mathrm{U}-50,488$ was found to be 10 times less potent than EKC in the rat tail-flick test. ${ }^{24}$

Ethylketazocine was stereospecific in its ability to affect bombesin-induced grooming in that the (+)-enantiomer was ineffective at doses at which the (-)-enantiomer had a significant effect. Tifluadom showed stereoselectivity, but not to as great an extent. Thus, $10 \mathrm{mg} / \mathrm{kg}$ of both the (t)- and (-)-isomers did suppress bombesin-induced grooming. However, $(-)$-tifluadom was significantly less effective than the $(+)$-isomer. The stereoselectivity of the ( + )-optical isomer of tifluadom (determined in ethanol) for opioid receptors has been observed previously in mice ${ }^{32}$ and monkeys. ${ }^{33}$ The (-)isomer of tifluadom has some affinity for the benzodiazepine receptor ${ }^{32.34}$ and may 
inhibit bombesin through this receptor; diazepam also inhibits bombesin-induced grooming at nonsedative doses (unpublished observation). This could be tested easily by examining the ability of naloxone to antagonize the actions of (-)-tifluadom on bombesin-induced grooming.

The ease at with which naloxone reversed the actions of EKC, U-50,488, and tifluadom on bombesin-induced grooming and the stereospecificity of naloxone in having this effect verifies that opioid receptors mediate their action. Naloxone is less potent at kappa than mu receptors. Its decreasing potency in antagonizing $\mathrm{EKC}$, tifluadom, and $\mathrm{U}-\mathbf{5 0 , 4 8 8}$ may therefore correspond to the increasing relative affinity of the three agonists for kappa over mu receptors. ${ }^{26}$

The development of tolerance to the ability of EKC to inhibit bombesin-induced grooming, taken together with the stereoselectivity, reversibility by naloxone, and the lack of effect of the nonopioid analgesic zomepirac indicate that opioid receptors mediate the attenuation of bombesin-induced scratching by analgesics. It becomes clear, however, based on tests of 35 opioid-like compounds with a large variety of chemical and pharmacological properties, that the kappa type of receptor is the only known opioid receptor linked to bombesin-induced grooming. Thus, mu opioid receptor agonists (morphine, codeine, levorphanol, heroin), mixed agonist-antagonists of the mu type (buprenorphine, nalbuphine), opioid antagonists (naloxone), peptides with mu- and delta-receptor activity ( $\beta$-endorphin, metkephamid, DPDPE), and chemically related nonopioids (dextrophan, thebaine) had no effect at nonsedative doses in this test. However, all the compounds tested that act at the kappa-type of opioid receptor were effective. Furthermore, the lack of tolerance to EKC in rats that received multiple injections of morphine is in agreement with the kappa-receptor specificity of opioid link to bombesin-induced scratching.

Dynorphin A was proposed as an endogenous ligand for the kappa receptor. ${ }^{35}$ However, its kappa receptor activity in vivo has been questioned. The dose-related antagonism of bombesin-induced grooming may be used as new evidence of a kappa-receptormediated effect of supraspinally administered dynorphin $A$. The inhibition of bombesininduced grooming occurred at doses similar to those at which dynorphin $A$ increased feeding in rats ${ }^{36}$ (another ef fect thought to be mediated by kappa receptors). Similarly, the attenuation of bombesin-induced grooming by xorphanol may be used as further evidence of the kappa agonist nature of this compound. ${ }^{38}$

Having established that opioids act through kappa receptors to affect bombesininduced scratching, we can speculate on the role of bombesin and opioids in scratching behavior. It is known that low doses of opioids acting at mu receptors (e.g., morphine and levorphanol) often cause scratching behavior in animals, and itching in humans. Bombesin given i.c.v. to morphine-dependent rhesus monkeys produces scratching behavior that is similar to, but more intense, than that observed following low doses of morphine in drug-naive monkeys (ref. 5 and unpublished observations). The itching produced by low doses of morphine is thought to be due to the release of histamine; however, it is not clear that histamine is the sole cause of this effect. In contrast, the acute administration of kappa opioids does not elicit scratching behavior. However, abstinence or naloxone-induced withdrawal behavior following the chronic administration of kappa opioids includes scratching as a prominent response. ${ }^{18,38}$ This behavior, and the possible role of bombesin in its production, needs to be studied further. Similarly, the role of bombesin in different types of pruritus and a possible link to kappa opioids should be investigated further. For example, opioids with kappa-receptor selectivity might be a drug class of choice for the relief of the pain and itching caused by small cell carcinoma of the lung, which is known to produce large amounts of bombesinlike immunoreactivity. ${ }^{39}$ 


\section{ACKNOWLEDGMENTS}

We thank the various individuals and pharmaceutical companies (listed in METHODS) who donated samples of the compounds used in these studies.

\section{REFERENCES}

1. Anastasi, A., V. Erspamer \& M. Bucci. 1971. Isolation and structure of bombesin and alytesin, two analogous active peptides from the skin of the European amphibians Bombesin and Alytes. Experientia 27: 166-167.

2. Brown, M. R., J. Rivier \& W. Vale. 1977. Bombesin: Potent effects on thermoregulation in the rat. Science 196: 998-1000.

3. GMEREK, D. E. \& A. CowAN. 1981. Tolerance and cross-tolerance studies on the grooming and shaking effects of ACTH (1-24), bombesin and RX 336-M. Fed. Proc. 40: 274.

4. Gmerek, D. E. \& A. Cowan. 1983. Studies on bombesin-induced grooming in rats. Peptides 4: 907-913.

5. Cowan, A., P. Khunawat, X. ZuZhu \& D. E. Gmerek. 1985. Effects of bombesin on behavior. Life Sci. 37: 135-145.

6. COWAN, A.\& D. E. GMEREK. 1981. Studies on the antinocisponsive action of neurotensin. Fed. Proc. 40: 273.

7. Dobry, P. J. K., M. R. Piercey \& L. A. Schroeder. 1981. Pharmacological characterization of scratching behaviour induced by intracranial injection of substance $\mathbf{P}$ and somatostatin. Neuropharmacology 20: 267-272.

8. GMEREK, D. E. \& A. Cowan. 1982. Bombesin-induced grooming is antagonized by benzomorphan analgesics but not by morphine. Fed. Proc. 31: 1301.

9. GMEREK, D. E. \& A. CowAN. 1982. Classification of opioids on the basis of their ability to antagonize bombesin-induced grooming in rats. Life Sci. 31: 2229-2232.

10. GMEREK, D. E. \& A. CowAN. 1983. ACTH (1-24) and RX 336-M induced excessive grooming in rats through different mechanisms. Eur. J. Pharmacol. 88: 339-346.

11. GMereK, D. E. \& A. Cowan. 1982. A study of the shaking and grooming induced by RX 336-M in rats. Pharmacol. Biochem. Behav. 16: 929-932.

12. Martin, W. R., C. G. Eades, J. A. Thompson, R. E. Huppler \& P. E. Gilbert. 1976. The effects of morphine- and nalorphine-like drugs in the nondependent and morphinedependent chronic spinal dog. J. Pharmacol. Exp. Ther. 197: 517-532.

13. GILBERT, P. E. \& W. R. MARTIN. 1976. The effects of morphine- and nalorphine-like drugs in the nondependent, morphine-dependent and cyclazocine-dependent chronic spinal dog. J. Pharmacol. Exp. Ther. 198: 66-82.

14. Hutchinson, M., H. W. Kosterlitz, F. M. Leslie, A. A. Waterfield \& L. Terenius. 1975. Assessment of the guinea pig ileum and mouse vas deferens of benzomorphans which have strong antinociceptive activity but do not substitute for morphine in the dependent monkey. Br. J. Pharmacol. 55: 541-546.

15. Kosterlitz, H. W., S. J. Paterson \& L. E. Robson. 1981. Characterization of the kappa subtype of opiate receptor in guinea-pig brain. Br. J. Pharmacol. 73: 939-949.

16. Woods, J. H., C. B. Smith, F. Medzihradsky \& H. H. Swain. 1979. Preclinical testing of new analgesic drugs. In Mechanisms of Pain and Analgesic Compounds. R. F. Beers, Jr. \& E. G. Bassett, Eds.: 429-445. Raven. New York.

17. Herling, S. \& J. H. Woods. 1981. Discriminative stimulus effects of narcotics: evidence for multiple receptor-mediated actions. Life Sci. 28: 1571-1584.

18. GmereK, D. E., L. A. Dykstra \& J. H. Woods. 1987. Kappa opioids in thesus monkeys: III. Dependence association with chronic administration. J. Pharmacol. Exp. Ther. 242: 428-436.

19. Lord, J. A. H., A. A. Waterfield, J. Hughes \& H. W. Kosterlitz. 1977. Endogenous opioid peptides: multiple agonists and receptors. Nature 267: 495-499.

20. GMEREK, D. E. \& A. CoWAN. 1984. In vivo evidence for benzomorphan-selective receptors in rats. J. Pharmacol. Exp. Ther. 230: 110-115. 
21. Porreca, F., R. B. Raffa, A. Cowan \& R. J. Tallarida. 1982. A comparison of the receptor constants of morphine and ethylketocyclazocine for analgesia and inhibition of gastrointestinal transit in the rat. Life Sci. 31: 1955-1961.

22. Romer, D., H. H.. Buscher, R. C. Hill, R. Maurer, T. J. Petcher, H. Zeuaner, W. Benson, E. Finner, W. Mnkowski \& P. W. Thies. 1982. An opioid benzodiazepine. Nature 298: 759-760.

23. Romer, D., H. H. Buscher, R. C. Hill, R. Maurer, T. J. Petcher, H. Zeugner, W. Benson, E. Finner, W. Mnkowski \& P. W. Thies. 1982. Unexpected opioid activity in a known class of drug. Life Sci. 31: 1217-1220.

24. Vonvolgtlander, P. F., R. A. LAhti \& J. H. Ludens. 1983. U-50,488: A selective and structurally novel non-mu (kappa) opioid agonist. J. Pharmacol. Exp. Ther. 224: 7-12.

25. Lahti, R. A., M. M. Mickelson, J. M. McCall \& P. F. Vonvolotlander. 1985. [ $\left.{ }^{3} \mathrm{H}\right] \mathrm{U}$ 69593, a highly selective ligand for the opioid kappa receptor. Eur. J. Pharmacol. 109: 281-284.

26. James, E. F. \& A. Goldstein. 1984. Site-directed alkylation of multiple opioid receptors. I. Binding selectivity. Mol. Pharmacol. 25: 337-342.

27. TANG, A. H. \& R. J. Collins. 1985. Behavioral effects of a novel kappa opioid analgesic, U-50,488, in rats and rhesus monkeys. Psychopharmacology 85: 309-314.

28. Murray, R. B., D. E. Gmerek, A. Cowan \& R. J. Tallarida. 1981. Use of a programmable protocol timer and data logger in the monitoring of animal behavior. Pharmacol. Biochem. Behav. 15: 135-140.

29. ALDER, H. L. \& E. B. Roessler. 1977. Introduction to Probability and Statistics, 6th edit. W. H. Freeman. San Francisco, CA. p. 337.

30. Tallarida, R. J. \& R. B. Murray. 1981. Manual of Pharmacologic Calculations with Computer Programs. Springer-Verlag. New York.

31. Upton, N., J. P. Gonzalez \& R. D. E. SEWEll. 1983. Characterization of a kappa-agonistlike antinociception action of tifluadom. Neuropharmacology 22: 1241-1242.

32. RUHLAND, M \& H. ZEUGNER. 1983. Effects of the opioid benzodiazepine tifluadom and its optical isomers on spontaneous locomotor activity of mice. Life Sci. 33(Supp.l): 631-634.

33. Dykstra, L. A., D. E. Gmerex, G. Winger \& J. H. Woods. 1987. Kappa opioids in rhesus monkeys. I. Diuresis, sedation, analgesia and discriminative stimulus effects. J. Pharmacol. Exp. Ther. 242: 413-420.

34. Kley, H., U. Scheidemantel, B. Berling \& W. E. Muller. 1983. Reverse stereoselectivity of opiate and benzodiazepine receptors for the opioid benzodiazepine tifluadom. Eur. J. Pharmacol. 87: 503-504.

35. Chavkin, C., I. F. James \& A. Goldstein. 1982. Dynorphin is a specific endogenous ligand of the kappa opioid receptor. Science 215: 79-81.

36. MoRley, J. E. \& A. S. LeVINE. 1983. Involvement of dynorphin and the kappa opioid receptor in feeding. Peptides 4: 797-800.

37. Howes, J. F., J. E. Villarreai, L. S. Harris, E. M. Essigmann \& A. Cowan. 1985. Xorphanol. Drug Alc. Dependence 14: 373-380.

38. Woods, J. H. \& D. E. GMerex. 1985. Substitution and primary dependence studies in animals. Drug. Alc. Dependence 14: 233-247.

39. Moody, T. W., C. B. Pert, P. I. F. Gazdar, D. N. Carney \& J. D. Minna. 1981. High levels of intracellular bombesin characterize human small-cell lung carcinoma. Science 214: $1246-1248$. 